\title{
PHYSICAL THEORIES IN THE SCHOOL COURSE
}

\author{
Nurbaeva D.M. ${ }^{l}$, Yerzhenbek B. ${ }^{l}$, Nurmukhamedova Zh.M. ${ }^{l}$, Nasirova D.M. ${ }^{l}$ \\ ${ }^{\text {I} A b a i ~ K a z a k h ~ N a t i o n a l ~ P e d a g o g i c a l ~ U n i v e r s i t y, ~ K a z a k h s t a n, ~ A l m a t y ~}$
}

\begin{abstract}
The content of the school physics course is the basics of science-physics, which is a system of knowledge about the world around us. An ideal model of nature that includes General concepts, principles, and hypotheses of physics and characterizes a certain stage of its development is called a physical picture of the world. The meaning of physical theory in science, concepts, laws, and theories are the source of specific knowledge in explaining and describing a particular phenomenon. The basic school physics course is a course that studies physical phenomena (mechanical, thermal, electrical, electromagnetic, light) and physical laws; the study material is grouped around physical phenomena, which are arranged in the course in order of complexity of the forms of motion of matter. The basic school physics course should be as complete as possible and cover the main material of all sections of the physics course.
\end{abstract}

Keywords: school physics, physical theories, phenomenon, notions, laws, experiment, classical mechanics, molecular-kinetic theory, electrodynamics and quantum theory.

\author{
Ац्датпа \\ Д.М. Нурбаева ${ }^{1}$, Б. Ерженбек ${ }^{1}$, Ж.М. Нурмухамедова ${ }^{1}$, Д.М. Насирова ${ }^{1}$ \\ ${ }^{1}$ Абай атындавы Қазақ ұлттық педагогикалық университеті, Алматы, Қазақстан \\ МЕКТЕП ФИЗИКА КУРСЫНДАҒЫ ТЕОРИЯЛАР
}

Мектептегі физика курсының мазмұнын қоршаған әлем туралы білім жүйесі болып табылатын физика ғылымының негіздері құрайды. Жалпы ұғымдарды, принциптерді, физика гипотезаларын қамтитын және оның дамуының белгілі бір кезеңін сипаттайтын табиғаттың нақты моделі әлемнің физикалық бейнесі деп аталады. Ғылыми физикалық теорияның мәні, ұғымдар, заңдар, теориялар белгілі бір құбылысты түсіндіруде және сипаттауда нақты білімнің қайнар көзі болып табылады. Негізгі мектептің физика курсы-бұл физикалық құбылыстарды (механикалық, жылу, электр, электромагниттік, жарық) және физикалық заңдылықтарды зерттейтін курс; оку материалы заттардың қозғалыс түрлерінің күрделену ретімен курста орын алған физикалық құбылыстардың айналасында топтастырылған. Негізгі мектептің физика курсы мүмкіндігінше аяқталған болуы керек және физика курсының барлық бөлімдерінің негізгі материалдарын қамтуы тиіс.

Түйін сөздер: мектеп физикасы, физикалық теориялар, құбылыс, ұғым, заңдар, тәжірибе, классикалық механика, молекулалық кинетикалық теория, электродинамика және кванттық теория.

\author{
Аннотация \\ Д.М. Нурбаева ${ }^{1}$, Б. Ерженбек ${ }^{l}$, Ж.М. Нурмухамедова ${ }^{1}$, Д.М. Насирова ${ }^{1}$ \\ ${ }^{1}$ Казахский национальный педагогический университет имени Абая, г. Алматы, Казахстан \\ ФИЗИЧЕСКИЕ ТЕОРИИ В ШКОЛЬНОМ КУРСЕ
}

Содержание школьного курса физики составляют основы науки-физики, которая представляет собой систему знаний об окружающем мире. Идеальную модель природы, включающую в себя общие понятия, принципы, гипотезы физики и характеризующую определенный этап ее развития, называют физической картиной мира. Значение физической теории в науке, понятия, законы, теории являются источником конкретных знаний в объяснении и описании определенного явления. Курс физики основной школы - это курс, в котором изучаются физические явления (механические, тепловые, электрические, электромагнитные, световые) и физические законы; учебный материал группируется вокруг физических явлений, которые располагаются в курсе в порядке усложнения форм движения материи. Курс физики основной школы должен быть по возможности завершенным и охватывать основной материал всех разделов курса физики.

Ключевые слова: школьная физика, физические теории, явления, понятия, законы, эксперимент, классическая механика, молекулярно-кинетическая теория, электродинамика и квантовая теория.

The basic school physics course can be studied for either three or two years in accordance with different systems of physical education. In the second case, students receive propaedeutic knowledge of physics in the course of natural science. In any case, the basic school physics course is a course that studies physical phenomena (mechanical, thermal, electrical, electromagnetic, light) and physical laws; the study material is 
grouped around physical phenomena, which are arranged in the course in order of complexity of the forms of motion of matter.

The inclusion of methodological knowledge in physics courses in high school devoted to works of scientists such as V. F. Efimenko, G. M. Golin, A. A. Buch, V. G. Razumovsky, I. B. Spassky, V. V. Multanovskiy, A. A. Pinsky, N. W. Purysheva etc. G. M. Golin [1] identified the following system of methodological knowledge:

1. The scientific experiment and methods the experimental (empirical) knowledge.

2. Physical theory and methods of theoretical knowledge.

3. Core methodological ideas of physics.

4. The main regularities of the development of physics (table 1).

Table 1. Structure of the physical picture of the world

\begin{tabular}{|l|l|l|}
\hline \multicolumn{2}{|c|}{ Physical picture of the world } \\
\hline \multicolumn{1}{|c|}{$\begin{array}{l}\text { Initial philosophical ideas and } \\
\text { concepts }\end{array}$} & \multicolumn{1}{|c|}{ Physical theories } & \multicolumn{1}{c|}{ Connections between theories } \\
\hline \multirow{3}{*}{$\begin{array}{l}\text { Matter, motion, space and time, } \\
\text { interaction. }\end{array}$} & $\begin{array}{l}\text { Classical mechanics } \\
\text { Statistical physics } \\
\text { Electrodynamics } \\
\text { Quantum theory }\end{array}$ & $\begin{array}{l}\text { Principles: correspondence, } \\
\text { complementarity, symmetry, } \\
\text { causality }\end{array}$ \\
\hline
\end{tabular}

One of the elements of this system is the physical theory and methods of theoretical knowledge. Physical theory is an integral system of physical knowledge that fully describes a certain range of phenomena and is one of the structural elements of the physical picture of the world.

The school physics course is built around four fundamental physical theories: classical mechanics, molecular kinetic theory, electrodynamics, and quantum theory. The theoretical core of the school physics course embodies these four fundamental theories, specially adapted for the school course. Physical theory in the course of physics at school. Materials chosen on the basis of physics course at school (phenomenon, notions, laws, theories) should be given to the pupils according to didactic principles. At present materials should be given systematically used in developmental teaching of pupils thinking ability. Because the content of scientific knowledge is increasing year by year, the time is short to learn it, the number of hour divided to physics is reducing. There are different ways of solving it. At present materials taught in the course of physics are united and grouped around physical ideas. Study materials in secondary school are collected and given around the basic idea and physical theories [2].

The importance of physical theory in science, notions, laws, theories are the source of concrete knowledge in explaining and describing definite phenomenon. The most important here is the theory does not explain only the phenomenon or process, also tells about the conduction of movement and implements new regularities. So, collecting the study material around physical theory is not the conclusion of gathering the knowledge to the pupils, it gives possibility to use and explain nature phenomenon of taken knowledge.

Therefore, uniting the study materials around physical theories forms the theoretical thinking ability of pupils, helps to know the life around us. It helps to realize the aims of teaching (educational, developmental, educative). From methodical point of view these aims are realized on the basis of learning study materials in basic school, using molecular-kinetic and electronic theories.

Molecular-kinetic theory is used at the beginning of physics course, then it is used in explaining the abilities of liquids and gases, heat phenomenon, aggregate condition of substances. Elements of electronic theory (structure of atom) are used in passing electrical and permeability phenomenon which is taught in basic school. In high classes of oriented school study material is grouped around classical mechanics, molecular-kinetic theory, electrodynamics and quantum theory. Here the materials are grouped according to the complexity of matter movement. The physics course in high school consists of four parts according to this group: mechanics, molecular physics, electrodynamics, quantum physics.

The part of mechanics provides all processes and phenomenon of mechanical movement of matter. Here matter point considers kinematics and dynamics of movement, conservation laws, mechanical movements and waves.

The part of molecular physics teaches phenomenon and processes according to heat movement of matter in micro and macro level, that is molecular-kinetic theory and thermodynamics. 
The part of electrodynamics includes all phenomenon and processes according to electromagnetic movement of matter: statistic, constant and temporary fields, questions according to permeability, electromagnetic movements, electromagnetic waves (radio and optical diapason), special comparative theory.

Phenomenon according to the energy is grouped in the part of quantum physics. Here photo effect phenomenon, atom structure, structure of atomic nucleus, elementary physics particles are considered.

Any theory basis, nucleus consist of the conclusions and its usage (figure1).

Experimental facts, material models, physical notions and quantities and their mutual influence comprise the basis of theory or its experimental base. Limited number of experimental facts is taken on the basis of theory description and learning. For example, Michelson experiment is taken in special comparative theory.

Theory nucleus includes laws, their mathematical model, postulates, principles and constancies. Values of constancies are measured in experiment.

Descriptions of concrete physical objects movement from theory nucleus, results and usage in solving concrete problems relate to the conclusions.

For example, experimental facts of ideal gas on experimental basis of molecular-kinetic theory: diffusion, quick squeeze of the gas, having the volume given to it. Ideal gas model, pressure that describes this ideal macrosystem, concentration, middle quadrate speed of molecule and other quantities comprise the basis of theory. Energies of micro particles, middle kinetic energy, basic equation of molecular-kinetic theory of ideal gas are nucleus theory. The equation of ideal gas condition, gas laws, internal energy, heat capaciousness that explain the gas abilities are related to theoretical conclusion.

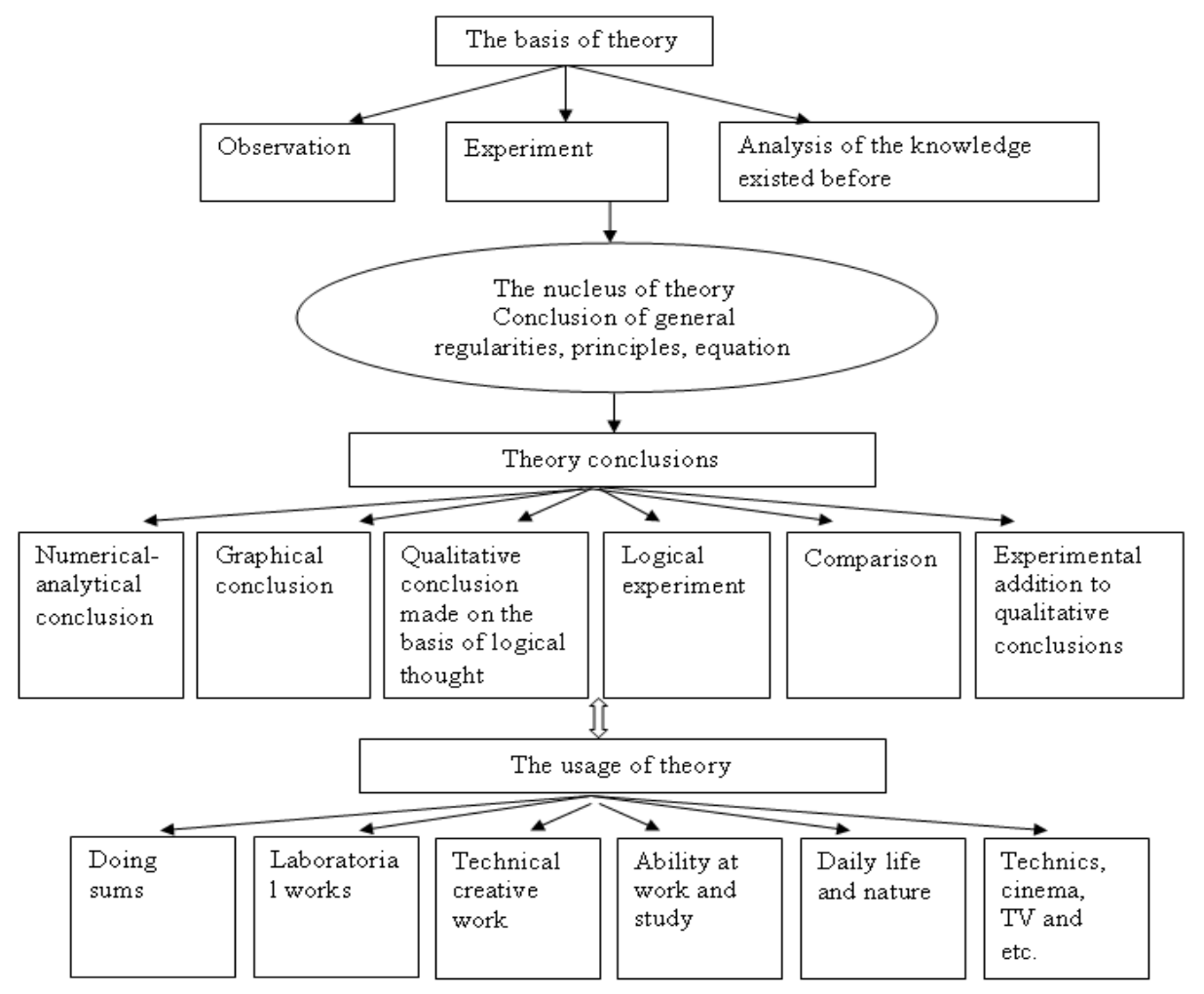

Figure 1. Structure of the physical theory

All these elements are included into the theory of molecular physics part in the course of physics. But the level of theory, their explanation is different, therefore it is given differently in the course of physics at school. Theoretical materials are grouped into that part in the course of physics. For example, the structure of mechanics in the part of Mechanics, the logics of situation are given according to solving the basic problem of mechanics. Therefore each type of movement is classified according to its initial terms and influencing force, here straight line and curve line movements are taught together.

Materials as statistic and constant fields in electrodynamics part are taught in succession, also they are grouped systematically in variable fields (variable electric and magnet). The questions are provided according to permeability in different environment in the part of electric current in different environment. 
Table 2. Structure of the classical Drude-Lorentz electronic theory

\begin{tabular}{|c|c|c|c|}
\hline \multicolumn{4}{|c|}{ CLASSICAL ELECTRON THEORY OF DRUDE-LORENTZ } \\
\hline Basis & The core & Consequences & Interpretation \\
\hline $\begin{array}{l}\text { The empirical } \\
\text { basis: } \\
\text { 1) The Rikke } \\
\text { Experience (1901); } \\
\text { 2) The experience } \\
\text { of Mandelstam and } \\
\text { Papaleksi (1913); } \\
\text { 3) the experience } \\
\text { of Tolman and } \\
\text { Stewart (1916). }\end{array}$ & $\begin{array}{l}\text { Main provisions of the theory: } \\
\text { 1) The Motion of electrons obeys } \\
\text { the laws of classical mechanics. } \\
\text { 2) Electrons do not interact with } \\
\text { each other. } \\
\text { 3) Electrons interact only with the } \\
\text { ions of the crystal lattice, this } \\
\text { interaction is reduced to a } \\
\text { collision. } \\
\text { 4) In the intervals between } \\
\text { collisions, the electrons move } \\
\text { freely. } \\
\text { 5) Conduction Electrons form an } \\
\text { electronic gas, like an ideal gas, the } \\
\text { "electronic gas" obeys the laws of } \\
\text { an ideal gas. }\end{array}$ & $\begin{array}{l}\text { Conclusion of Ohm's } \\
\text { law. } \\
\text { Explanation of the } \\
\text { nature of metal } \\
\text { resistance. } \\
\text { Derivation of the Joule- } \\
\text { Lenz law. }\end{array}$ & $\begin{array}{l}\text { Limits of applicability and } \\
\text { disadvantages of the theory: } \\
\text { The classical theory can not } \\
\text { explain the law of Dulong } \\
\text { and Pti, the temperature } \\
\text { dependence of the resistivity } \\
\text { of metals, superconductivity. }\end{array}$ \\
\hline
\end{tabular}

The structure of physical theory presented in table 4 can be used to structure the content of the generalizing lesson on the topic «Electric current in metals», which is the first lesson in the study of the topic «electric current in various media» in grade 10. Generalization and systematization of knowledge at the level of physical theory contributes to students awareness of methodological knowledge, understanding the logic of the process of cognition. It is very important in this case that the process of learning appears to students in dynamics. It is in this case that the methodological nature of knowledge can be most fully reflected. In accordance with this, the deployment of educational material should be carried out according to the stages of the knowledge cycle: experimental facts $>$ hypothesis (model) $>$ theoretical consequences $>$ experiment (see table 3). In this case, the reference summary in the student's notebook can be presented in the form of table 2.

Table 3. Generalization of educational material when studying the topic «Electric current in metals».

\begin{tabular}{|c|c|c|c|}
\hline Evidence & Hypotheses & Theoretical implications & Experiment \\
\hline $\begin{array}{l}\text { 1) The Rikke Experience } \\
\text { (1901); } \\
\text { 2) The experience of } \\
\text { Mandelstam and Papaleksi } \\
\text { (1913); } \\
\text { 3) The experience of Tolman } \\
\text { and Stewart(1916). }\end{array}$ & $\begin{array}{l}\text { Electronic conductivity } \\
\text { of metals. Model of free } \\
\text { electron motion in a } \\
\text { crystal lattice in the } \\
\text { absence and presence } \\
\text { of an electric field }\end{array}$ & $\begin{array}{l}\text { Conclusion of Ohm's law. } \\
\text { Derivation of the Joule- } \\
\text { Lenz law. } \\
\text { Explanation of the nature of } \\
\text { metal resistance. }\end{array}$ & $\begin{array}{l}\text { Experimental } \\
\text { verification of the } \\
\text { laws of Ohm and } \\
\text { Joule-Lenz. }\end{array}$ \\
\hline
\end{tabular}

Considering the limits of applicability of the Drude-Lorentz theory will protect students from dogmatism in the study of physics. It is very important that the material studied is not considered by students as a complete scheme, devoid of contradictions. It is necessary that students understand that absolute truth is not achievable, and the process of learning is a constant pursuit of absolute truth through a series of relative truths that replace each other. Thus, the teacher leads them to understand the essence of the methodological principle of conformity. (Later, we can also touch on the content of another methodological principle - the complementarity principle, pointing out that the Maxwell theory and the Drude-Lorentz theory describe the phenomenon of electrical conductivity from different points of view and thus complement each other.)

Waves of light as the separate part of electromagnetic wave is included in the theme of electromagnetic waves. Geometrical optics part is learnt as limited condition of wavy optics.

The basic ideas of considering the physics course: structure of matter, conservation law of energy and comparative. Learning the matter structure by the pupils is formed after the beginning of physics subject. After that pupils acquaint with the field that is one type of matter. In high classes of oriented school these outlooks are developed and deepened, connection between the substance and field and electromagnetic field notion are included. Conservation laws are used in all parts of physics course. Pupils learn conservation laws 
of energy and impulse at basic school. Conservation laws are used to explain different nature of mechanical, heat, electromagnetic, quantum phenomenon in physics.

Grouping the study material around physical theory forms theoretical thinking ability of pupils.

Theoretical conclusion, systematization of the content in learning the physics are the basis of theoretical thinking ability. Scientific cognitive periods in teaching:

$$
\text { facts } \rightarrow \text { model } \rightarrow \text { results } \rightarrow \text { experiment. }
$$

Formation of theoretical thinking method puts new requirements to the experiment. Experiment plays the important role in the periods of gathering the knowledge, usage and checking of taken knowledge. Therefore most attention is paid to the experiment in physics course of secondary school. Here experiments that coincide with the theory are taught (Ioffe-Milliken, Rezerford, Shtern, Faradei, Ersted, Amper and others). Some part of teaching is given to the demonstrative experiment and experiment made by the pupils.

Most attention is paid to learning of pupils and formation of world physical image in making the experiment. Grouping and systematizing the content of physics course around physical theories give possibility to solve the formation of scientific outlook of pupils. When the physics course has been finished, world physical image should be formed. World physical image consists of physical theories.

Organization of systematization and concluding according to the periods of study material gives possibility to solve successfully giving polytechnical knowledge. Consideration of physics laws usage in practice is the end of cognitive process. In physics course of the school that gives general knowledge polytechnical materials are given systematically in basic scientific-technical progress direction, that is around coincided parts (mechanization-mechanics, heat physics-thermodynamics, energetic - electrodynamics and other parts). Here applied materials are closely connected with the theory. So all physical materials are given in basic school and oriented school on the basis of physical theories (mechanics, molecular physics, electrodynamics and quantum physics). Future physics teacher uses his knowledge in teaching concrete theme, gets good results when he uses the development history of physics giving examples from life and concluding and systematizing the course materials scientifically.

Method of learning physical theories. Learning physical theories form theoretical thinking ability of pupils [3]. In physics program of 7-9 classes of basic school molecular-kinetic theory of substance structure, electronic theory and atomic structure are taught. Consider the basic principles of learning elements of physical theory in 7-9 classes. While learning definite theory materials given to pupils should coincide with present scientific outlooks. The knowledge taken from physics course at school should be proved and concretized in high classes of oriented school. The principle according to each theory should be based through the analysis and conclusion of experimental facts taken with the help of observation of physical phenomenon in the environment or physical experiment of pupils according to the possibility [4-6].

These requirements should be put to mastering the theory of basic school pupils:

- to know the basic principles of theory;

- to analyze the facts based on the analysis of theory;

- to define the phenomenon understood by that theory; to make experiment and use in practice to explain observed phenomenon.

Theoretical conclusion is used in forming the physical theory in cognitive process. Theoretical conclusion can be divided into several periods:

I period. Collection and analysis of the facts related to the action of the person according to the subject. Learning and choosing the facts given specially in teaching process, comparison with other information, to teach pupils to new notion, regularity by making observation and experiment.

II period. Concluding and gathering physical quantity, law or equality, postulates to different model by abstract method.

III period. Taking and concretizing the reason result connections of abstract formulas, laws, principles came from basic regularity. In this period the conclusion of taken knowledge, logical thinking are realized by conclusion methods in mathematical form. The peculiarity related to physics is to define by the experiment while making the experiment separate regularities taken through the experiment, numerical values of constancies and quantities.

$I V$ period. To use taken knowledge to concrete physical objects and phenomenon. The pupils explanation of natural phenomenon and processes passing in the industry and solving different sums are the conclusion of making the experiment of laws and theories.

The above given theoretical concluding periods coincide with the periods of teaching cycle: $I-f a c t s, I I-$ model, III-conclusion-experiment. 
Initial abstract conclusion is given in ready form to the pupils in teaching process. For example, the law of $\mathrm{Om}$ is given to pupils as an experiment or conclusion made in class, but connections among physical

quantities approximated is equal to: $I=\frac{U}{R}$. Above given periods are noticed well in learning initial notions of physics such as speed, force, pressure, also in reading Om, Kulon, Faradei laws, especially physical theories. For example, while teaching Newton laws pupils are explained by definite facts, observations and making experiment [5]. Physics course in basic school, notions according to substance structure -atom, molecule, solid, liquid, gas substances, also physical quantities -speed, mass, force, pressure and etc. Then these notions are concluded systematizing in forming laws of physics course. In order to learn new laws new notions are included, others are generalized.

Conclusion conducted in physics course at high classes of oriented school is defined by the level than basic school according to physical theories: classical mechanics, molecular physics and quantum physics. Physics course is ended with conducting generalizing lesson in qualified form according to formation of world physical image (WPI). There are peculiarities of pupils cognitive process of knowing the physical regularities on the level WPI, notions, laws, theories. This coincides with the periods of theoretical conclusion of implementing the pupils cognitive thinking in succession in organization of educational process, structure of study materials. So, learning physical theories helps to understand rightly physical phenomenon, life, phenomenon in the industry and world physical image (WPI).

\section{Acknowledgements}

The work was published within the framework of the received grant IRN № AP08052997 «Updating the content of educational programs for training teachers in natural science subjects in the context of modernization of secondary education», funding source - Ministry of Education and Science of the Republic of Kazakhstan.

References:

1 Голин Г.М. Вопросы методологии физики в курсе средней школьы. - М. Просвещение, 1987.

2 Құдайқұлов М., Жаңабергенов Қ., Орта мектепте физиканы оқыту әдістемесі.-Алматы., 1998.

3 Yerzhenbek B., Sydykova Zh.K., Nurmuhamedova Zh.M., Nurbaeva D.M. Basic tasks of teaching physics at school. // Bопросы педагогики.-Москва, 2020. -8-15c.

4 Бамарұлы Р. Физика. Жалпы білім беретін мектептің 7-сыныбына арналван оқулық. - Алматы: Атамұра, 2017. -208 б.

5 Кронгарт Б.А., Насохова Ш. Б. Физика. Жалпы білім беретін мектептің 8-сыныбына арналван оқулық..Алматы: Мектеп, 2018. - 2326.

6. Жалпы білім беретін мектептің 9-сыныбына арналван окулық. - Нұр-Сұлтан: Арман-ПВ, 2019.- 2726.

References

1 Golin G.M. (1987) Voprosy metodologii fiziki v kurse srednej shkoly [questions of physics methodology in the course of the middle school]. Prosveshhenie. (In Russian)

2 Qudajqulov M., Zhanabergenov Q. (1980) Orta mektepte fizikany oqytu adistemesi [methods of teaching physics in secondary schools]. Almaty. (In Kazazkh)

3 Yerzhenbek B., Sydykova Zh.K., Nurmuhamedova Zh.M., Nurbaeva D.M. (2020) Basic tasks of teaching physics at school. Voprosy pedagogiki. Moskva. 8-15. (In English)

4 Basharuly R. (2017) Fizika. Zhalpy bilim beretin mekteptin 7-synybyna arnalgan oqulyq [Physics. Textbook for the 7th grade of a general education school]. Almaty, Atamura. 208. (In Kazazkh)

5 Krongart B.A., Nasohova Sh. B. (2018) Fizika. Zhalpy bilim beretin mekteptin 8-synybyna arnalgan oqulyq [Physics. Textbook for the 8th grade of a general education school]. Almaty, Mektep. 232. (In Kazazkh)

6. (2019) Zhalpy bilim beretin mekteptin 9-synybyna arnalgan oqulyq [textbook for the 9th grade of a general education school]. Nur-Sultan, Arman-PV, 272. (In Kazazkh) 